\title{
Effects of Workshops on the Early Childhood Educators' Perceptions of STEM Practices
}

\begin{tabular}{ccc}
\hline Article Type & Received Date & Accepted Date \\
Research & 9.09 .2020 & 31.05 .2021 \\
\hline
\end{tabular}

\section{Seçil Yücelyiğit*}

\begin{abstract}
This study aimed at exploring the effects of early STEM workshops on preschool teachers' perceptions of STEM practices in the early childhood classroom. The research adopted a concurrent triangulation strategy with maximum variation/heterogeneous purposive sampling. The participants of the study are 44 preschool teachers who participated in a STEM workshop designed for preschool teachers. The study utilized two instruments for data collection. For the quantitative data, a survey and a rubric to score the survey is developed and the qualitative data is collected by a semistructured interview form developed by the researcher. Paired samples t-test was performed to determine if preschool teachers' perceptions about early childhood STEM education differed after the STEM workshop they participated. The analysis revealed that preschool teachers' perceptions of early STEM education changed significantly $(\mathrm{p}=.000, \mathrm{~N}=44)$ from pre to post-survey. Thematic analysis was employed to examine the qualitative data. Findings of the thematic analysis revealed that both the preschool teachers' views about the effects of STEM workshops and their recommendations for an effective STEM workshop fall under six categories. The contribution of this study to the field is to provide quantitative data on the effect of STEM workshops on preschool teachers' perceptions of early STEM practices and to determine the needs of preschool teachers to improve STEM implementations in their classrooms. The research concludes with the discussion of its findings and recommendations for further research.
\end{abstract}

Keywords: STEM education, STEM workshop, professional development, STEM practices, early childhood educator, preschool teacher.

* Assist. Prof. Dr., TED University, Faculty of Education, Department of Early Childhood Education, Ankara, Turkey. E-mail: secil.yucelyigit@ tedu.edu.tr, https://orcid/0000-0002-6886-5997 


\title{
STEM Atölye Çalışmalarının Okul Öncesi Eğitimcilerinin Erken Çocuklukta STEM Uygulama Algılarına Etkisi
}

\begin{abstract}
Makale Türü
Başvuru Tarihi

Kabul Tarihi

Araştırma

9.09.2020

31.05 .2021

\section{Seçil Yücelyiğit*}

$\ddot{O} z$

Bu çalışma, erken dönem STEM atölye çalışmasının okul öncesi öğretmenlerinin erken çocukluk sınıfındaki STEM uygulamalarına ilişkin algıları üzerindeki etkilerini araştırmayı amaçlamaktadır. Araştırma, karma yöntem tasarımlarından biri olan eşzamanlı üçgenleme stratejisinde tasarlanmıştır. Araştırmanın katılımcıları, erken çocukluk için bir STEM atölyesine katılan 44 okul öncesi öğretmenidir ve maksimum varyasyon / heterojen amaçlı örnekleme oluşturmaktadır. Çalışmanın nicel verileri araştırmacı tarafından geliştirilen anket ve puanlama tablosu aracılığıyla, nitel verileri ise yarı yapılandırılmış görüşme formu aracılığıyla toplanmıştır. Okul öncesi öğretmenlerinin katıldıkları STEM çalıştayından sonra erken çocuklukta STEM eğitimine bakış açılarının farklılaşıp farklılaşmadığını belirlemek için eşli örneklem t-testi yapılmıştır. Analiz, okul öncesi öğretmenlerinin erken dönem STEM eğitimine ilişkin bakış açılarının anket öncesinden sonrasına göre önemli ölçüde değiştiğini $(\mathrm{p}=.000, \mathrm{~N}=44)$ ortaya koymaktadır. Nitel veri analizi için, yarı yapılandırılmış görüşme formlarının değerlendirilerek temaların oluşturulduğu tematik analizden yararlanılmıştır. Tematik analizin bulguları, okul öncesi öğretmenlerinin katıldıkları STEM çalıştayının etkisine ilişkin görüşlerinin ve STEM çalıştayı için önerilerinin her ikisinin de altı kategori oluşturduğunu ortaya koymaktadır. Bu çalışmanın alana katkısı, STEM atölye çalışmalarının okul öncesi öğretmenlerinin algılarına etkisine yönelik nicel veri sunması ve okul öncesi öğretmenlerinin sınıflarında STEM uygulamaları geliştirebilmeleri için duyulan ihtiyacın belirlenmesidir. Uygulama önerileri ve ileri çalışmalar araştırmanın bulguları doğrultusunda tartışılmıştır.
\end{abstract}

Anahtar Sözcükler: STEM eğitimi, STEM atölyesi, mesleki gelişim, STEM uygulamaları, erken çocukluk eğitimcisi, okul öncesi öğretmeni.

\footnotetext{
* Dr.Öğr. Üyesi, TED Üniversitesi, Eğitim Fakültesi, Temel Eğitim Bölümü, Okul Öncesi Eğitimi Anabilim Dalı, Ankara, Türkiye. E-posta: secil.yucelyigit@tedu.edu.tr, https://orcid.org/0000-0002-6886-5997
} 


\section{Introduction}

In the last few years, there has been a striking increase in the studies of STEM approach during the early years. The results of the research conducted on STEM education in early childhood have revealed the necessity of starting STEM practices in the preschool period (Akgündüz \& Akpınar, 2019; Brennaman, Lange \& Nayfeld, 2019; Bybee, 2013; MacDonald \& Rafferty, 2016; Moomaw, 2013). Campbell, Speldewinde, Howitt, and MacDonald (2018) define the early years as the critical period when children lay the foundation for their future STEM understandings. STEM education assembles science and mathematics with engineering discipline to find solutions to the problems encountered or to develop innovative products by integrating technology in the process (Bybee, 2013; Çorlu, Capraro and Capraro, 2014; Moomaw, 2013). Research on experimental studies that focus on STEM practices and address the preschool children report the significant contribution of the implemented practice on children's learning or development (Alade, Lauricella, Beaudoin-Ryan \& Wartelle, 2016; Aldemir \& Kermani, 2017; Bers, Seddighin \& Sullivan, 2013; Dejonckheere, Wit, Keere \& Vervaet, 2016; Kermani \& Aldemir, 2015; Master, Cheryan \& Meltzoff, 2017). There are also descriptive survey studies that set the scene for further research and steps to be taken for effective and qualified implementations on early STEM education (Ong et al. 2016; Polat \& Bardak, 2019; Yildırım, 2020). The findings of these studies are in need to be evaluated rigorously and steps need to be taken by considering the recommendations.

Literature review on pre-school teachers' perceptions and interests in STEM subjects indicates that a considerable number of prospective preschool teacher trend low towards science and mathematics subjects (Copley and Padrón 1999; Greenfield et al., 2009; Uğraş and Genç, 2018). In their study Günşen, Uyanık and Akman (2019) concluded that $60 \%$ of the participating teachers do not know how to use the STEM approach in their classes. On the other hand, the Ministry of National Education (MoNE) emphasizes integrating STEM in the education program and curriculum starting from preschool level (MoNE, 2018) as it is the case for the developed and developing countries like the USA, Germany, Australia, Singapore, Taiwan and more others (MacDonald, Huser, Sikder \& Danaia, 2019; Ndijuye \& Tandika, 2020). Preschool teachers who are expected to integrate STEM approach in their teaching need to be supported to be more equipped in fulfilling this expectation.

The research results determine the teachers' motivation to enrich their program with STEM practices and their aspirations for getting trained on the STEM subjects that they feel weak (Yildirım, 2018; Yıldırım 2020; Wang, Moore, Roehrig \& Park, 2011). It is thought that presenting the opportunity to the preschool teachers who demand training on STEM subjects, will contribute to the implementation of STEM practices and the intended effects of them on children. Workshops are regarded as an opportunity to develop hands-on implementations on a subject after being instructed about the theoretical framework and basic principles of a specific subject by a professional expert. The last decade witnessed a growing number of workshops for teachers who are interested in their professional developments on various subjects and STEM education is one of them (Chen, Huang \& Wu, 2020; Nadelson, Seifert, Moll \& Coats, 2012; Havice, Havice, Waugaman, \& Walker, 2018). When the target group of STEM workshops offered for teachers is analyzed, it is seen that most of them address the elementary or high school level (Altuger-Genc, \& Issapour, 2015; Çavaş, Yar, Bula Turuplu, \& Gürcan, 2019; Yildirım, 2020). Considering the emphasis on the early start for STEM practices, it is recommended that the workshops should be planned to target the same period.

Studies about professional development for teachers on STEM approach provide a framework that determines the purpose and components of an effective STEM workshop. The results of Brenneman, Lange and Nayfeld (2019) and Aşık, Doğança Küçük, Helvacı and Çorlu's (2017) studies conclude that the workshops should address the needs of teachers, provide hands-on opportunities that can be implemented in their classes and be adapted to their own teaching environment. Both of these studies offer four sessions of workshops as part of their professional development program. Findings of a study by Gardner, Glassmeyer and Worthy (2019) indicate that the workshop on STEM education that meets the middle and secondary school teachers' needs have a positive impact on their professional development.

Equipping preschool teachers with STEM subjects is expected to make a difference in preschool children's achievement in STEM. This reveals the importance of early period STEM workshops 
provided for preschool teachers. Although the research on the effects of STEM workshops on teachers' perceptions about STEM practices exist, they address the level later than the preschool period. In this study, the effects of STEM workshops on preschool teachers' perceptions of STEM practices in early childhood education are explored. In this regard, a mixed-method study is conducted with the aim of collecting both quantitative and qualitative data. Given this goal the research questions are set as follows:

1) Is there a meaningful difference in preschool teachers' perceptions of early STEM practices after participating in the STEM workshop?

2) Does the change in preschool teachers' pre and post workshop scores differ significantly according to their demographic charecteristics?

3) How do the preschool teachers reflect on the effects of the STEM workshop on their perception of STEM practices in early childhood?

\section{Method}

\section{Research Design}

This mixed-method study adopted a concurrent triangulation strategy in which quantitative and qualitative data is collected concurrently in one phase and merged in another phase. In this research the purpose to use the concurrent triangulation design is to determine and interpret the difference in preschool teachers' perceptions on early STEM practices after participating in STEM workshop. The quantitative data were collected by a survey and evaluated by a rubric designed for the study. The qualitative data were collected via semi-structured interview forms. Below, the research design is presented in a diagram (Figure1).

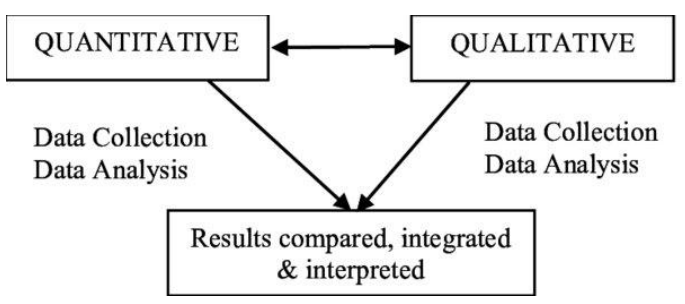

Figure 1. Research design of the study in diagram

As seen in Figure 1 the quantitative and the qualitative data is collected and analyzed concurrently and the findings are interpreted together. This design not only establishes the validity of the study but also elaborates and complements the findings by integrating results from different methods (Creswell \& Creswell, 2017).

\section{Research Sample}

The participants in the study constitute a maximum variation/heterogeneous purposive sampling. This type of sample provide as much insight as possible into the event or phenomenon under examination. The sample consisted of 55 in-service preschool teachers who participated in the STEM workshop. All of the participants were female, 39 of them were familier with STEM approach, 5 of them had experience of designing STEM activities in their classes. 11 of the participants had missing information in their survey and had to be excluded from the data analysis. The demographics of the valid participants $(\mathrm{n}=44)$ are presented in Table 1 below.

All of the participants signed the consent form which declared that they are authorized to drop out of the study if they choose to do so without any questioning. The researcher assured the data confidentiality of the obtained data and kept all the data anonymized without sharing with other parties. 
Table 1

The Demographic Informantion of the Participants $(n=44)$

\begin{tabular}{ll}
\hline School-type & $\mathbf{N}$ \\
\hline State & 39 \\
Private & 5 \\
\hline Graduation & $\mathbf{N}$ \\
\hline Vocational high school & 6 \\
Undergraduate & 32 \\
Graduate (MSc) & 6 \\
\hline Experience & $\mathbf{N}$ \\
\hline 4-5 years & 4 \\
6-10 years & 12 \\
11-20 years & 19 \\
More than 21 & 9 \\
\hline
\end{tabular}

\section{Research Instruments and Procedures}

The STEM workshop was designed by the researcher as a result of an extensive and rigorous literature review. The workshop is specifically planned for the in-service preschool teachers. The researcher had the experience of giving STEM integration lectures to prospective preschool teachers. The workshop aimed at 1) introducing what is meant by engineering skill at preschool level 2) presenting a step by step model to involve engineering and technology in integrated early science and mathematics concepts 3) collaboration on hands-on early STEM activities and 4) enhancing the group works after the feedbacks and discussions with all participants.

The workshop took two days (16 hours) in four sessions. As intended with the workshop, first, the theoretical framework for the STEM approach and STEM education in the early years was presented. Second, the samples were shared and discussed. Third, the participant practice session was held. Finally, participants presented and shared their works and detailed feedback was provided for each group for evaluation.

The study utilized two instruments for data collection. The first tool is Preschool STEM Practices Perception Survey and the rubric to score the survey. The second tool is the semi-structured interview form on the preschool teachers' perceptions of the effects of the STEM workshop they participated in.

\section{Preschool STEM Practices Perception Survey}

The survey included six questions to measure participant preschool teachers' level of perceptions on using integrated science and mathematics activities enhanced with technology and engineering design in early childhood education. The questions include participant preschool teachers' aspiration to use in-class science and mathematics activities, the way they apply the activities, use of technology and use of engineering design skills during science and mathematics activities, their opinion about the suitability and the feasibility of integrated STEM activities at the preschool level. The answers of the participants were scored as 0 for negative answers and 1 for positive answers (for the question about the way they use science and mathematics activities, integrated was scored as 1 and separated was scored as 0 ) and accordingly the total test score range was between 0-6.

\section{Effects of STEM Workshops Interview Form}

The second tool, semi-structured interview form consisted of two open-ended questions. The questions are as follows:

1. How do you define the effect of the workshop you participated in, on your perception of using STEM activities in the preschool classroom?

2. What would your recommendations be to enhance the effect of this workshop? 


\section{Reliability and Validity of the Measurements}

The questions of the survey and semi-structured interview form were selected by a group of academics on early childhood education, science and mathematics education and an educational technologist from a list of more questions prepared after an extensive literature review. Six questions for Preschool STEM Practices Perception Survey and two questions for Effects of STEM Workshops Interview Form were found to be proficient and expedient to achive the goals of the study by the consulted expert group. For the reliability, the answers of the pilot test was scored by two different raters to see if the survey score is consistent. The scores of the two raters for the survey were coherent and the group of consulted experts validated that the survey can be used for the intended purpose. To establish coding credibility of the interview forms, a colleague was asked to code the same data. The similarities and differences between the two sets of codes were discussed and reached a consensus on internal and external data consistency. After all, the measurement tools were found to be valid and reliable to be used for the purpose of the study.

\section{Data Analysis}

Both the quantitative and qualitative data collected in the research were saved digitally on a computer without any alteration or correction and analyzed separately. In the study, the sample size with valid data is 44 . Since the sample size is large enough, the central limit theorem ensures the normal distribution. Since Shapiro Wilk test results stronger for the samples less than 50, the normality assumption was tested with the Shapiro Wilk test (Büyüköztürk, 2013). The result for the test of normality is calculated as $.805(\mathrm{p}<.001)$. After ensuring the normality of the difference between pairs, a paired t-test was conducted to examine the effect of the workshop on preschool teachers' perceptions about early STEM education. The paired t-test is used to determine whether the mean of a dependent variable differs in a group (Büyüköztürk, 2013). In this study, the means for pre and post-test results are examined as the dependent variable before and after the intervention which is the STEM workshop. The data were also analyzed for their effect by demographics of the participants. Levene's statistic was taken into consideration for the homogeneity of the variance for the participant teachers' in-service experience period, school-type they work and the school they graduated from. For the quantitative data analysis SPSS (Version 21) was utilized.

Thematic analysis was employed to examine the qualitative data and to form the themes drawn on the semi-structured interview forms. The participants were indexed as $\mathrm{K} 1, \mathrm{~K} 2, \ldots$ to $\mathrm{K} 44$ for the confidentiality of personal information so that the names remained anonymous. Then the answers to the open-ended questions were coded. Coding refers to the identification of topics, issues, similarities, and differences revealed through the participants' narratives (Sutton \& Austin, 2015). For the thematic analysis of the data, MaxQDA (2018 Version) was utilized.

\section{Results}

The t-test, and ANOVA results are shared in this section along with the major themes defined by thematic analysis. Table 2 summarizes the means and standard deviations of the pre and post-survey data. Paired samples t-test was performed to determine if preschool teachers' perceptions on early years STEM education differed after the STEM workshop they participated.

Table 2

Paired Samples $t$-test Statistics and Results for the Pre and Post-Test $(n=44)$

\begin{tabular}{lllcc}
\hline & Mean & Std. Dev. & t & p \\
\hline Pre-survey & 1,75 & 1,102 & 12,974 &, $000^{*}$ \\
Post-survey & 5,16 & 1,346 & & \\
\hline * $<.01$ & & & &
\end{tabular}

The results from the pre-survey $(M=1.75, S D=1.1)$ and post-survey $(M=5.16, S D=1.3)$ indicate that the STEM workshop they participated resulted with a significant difference in the participant teachers' perceptions of early years STEM education, $\mathrm{t}(44)=12.97, \mathrm{p}=.000$.

One way ANOVA was performed to determine if the pre and post survey scores differ significantly according to the demographics of the participants and the results are shared in Table 3 below. 
Table 3

ANOVA Results for the Difference of Pre and Post-Test by Demographics ( $n=44)$

\begin{tabular}{|c|c|c|c|c|c|c|}
\hline & & Sum of Squares & df & Mean Square & $\mathbf{F}$ & p \\
\hline \multirow[t]{3}{*}{ School type } & Between-groups & 202 & 3 & 067 & ,636 & ,596 \\
\hline & Within groups & 4,230 & 40 & 106 & & \\
\hline & Total & 4,432 & 43 & & & \\
\hline \multirow[t]{3}{*}{ Graduation } & Between-groups & 1,865 & 3 & 1,776 & 1,197 & ,323 \\
\hline & Within groups & 20,771 & 40 & ,896 & & \\
\hline & Total & 22,636 & 43 & & & \\
\hline \multirow[t]{3}{*}{ Experience } & Between-groups & 5,329 & 3 & .067 & 1,983 & ,132 \\
\hline & Within groups & 35,830 & 40 & .106 & & \\
\hline & Total & 41,159 & 43 & & & \\
\hline
\end{tabular}

The results in Table 3 indicate that there was no significant difference in participants' pre and post survey scores according to their demographic information on school type they work, school they graduated from and their in-service experience period.

The qualitative data set consists of two open-ended questions. Based on the interview transcripts, the themes for the first question are categorized as shown in Table 4.

Table 4

Themes and Frequency for Question 1 of Effects of STEM Workshops Interview Form

\begin{tabular}{ll}
\hline & f \\
\hline Knowledge acquisition & 29 \\
Alternating view-point & 14 \\
Deficiency make-up/correction & 3 \\
Contribution of implementation & 1 \\
Colleague interaction & 1 \\
No comment & 8 \\
\hline
\end{tabular}

Table 4 shows that the preschool teachers' views about the effects of STEM workshop they participated falls under six categories which are knowledge acquisition (29 participants), alternating view-point (14 participants), deficiency make-up/correction (3 participants), contribution of implementation (1 participant), colleague interaction (1 participant) and finally the participants who did not declare their view about this question was categorized as no comment (8 participants).

As it is seen in Table 4 majority of the participants (29) defined the effect of the STEM workshop in relation with knowledge acquisition which is an evidence that most of the participants lacked the knowledge about STEM approach in early childhood. Some of the participant teachers' views about knowledge acquisition effect are as follows:

K27 (Undergraduate, working in a state school, having an experience over 21 years): "I was trying to implement STEM activities in my classroom but in this workshop I learned practical knowledge that I can apply such as the priorities and some other tips that make it easier. I think I deepened my knowledge. The samples shared at the beginning of the workshop and the one we tried ourselves later on, have also contributed to my understanding."

Of the 44 participants in total, 14 of them preferred to point out the effect of the STEM workshop under alternating viewpoint theme. Views of $\mathrm{K} 9$ can be regarded as an example for this.

K9 (Graduate (MSc), working in a state school, having an experience of 11-20 years): "Before participating in the workshop, I was assuming that STEM approach is only about robotics, electronics and stuff like that. But I realized that this is not the case, we need to focus on suitability and applicability to everyday life. I realized that I could improve myself more and apply in my classes. I am leaving in accordance with my purpose of participation. Thank you."

Regarding the deficiency make-up/correction theme, view of 3 participants represented this category. One of the participants in the study said:

K17 (Undergraduate, working in a state school, having an experience of 11-20 years): "The workshop was definitely effective. I have noticed that there are some stages that I have applied incorrectly and I believe that I will do more conscious implementations from now on." 

Table 5 .

Based on the interview transcripts, the themes for the second question are categorized as shown in

Table 5

Themes and Frequency for Question 2 of Effects of STEM Workshops Interview Form

\begin{tabular}{ll}
\hline & f \\
\hline Duration of the workshop & 9 \\
Expansion of capacity & 9 \\
Number of samples shared & 8 \\
Frequency of the workshop & 6 \\
Practice group size & 2 \\
Other & 2 \\
\hline
\end{tabular}

Table 5 shows that the preschool teachers' recommendations about the ways to enhance the effect of STEM workshop they participated falls under six categories which are duration of the workshop ( 9 participants), expansion of capacity (9 participants), number of samples shared (8 participants), frequency of the workshop (6 participants), practice group size ( 2 participant) and finally other theme (2 participants).

As it is seen in Table 5, 9 of the participants made recommendations about the duration of the workshop to enhance the effect of it. One of the participants in the study said:

K28 (Undergraduate, working in a state school, having an experience of 11-20 years): "It may take a little longer to be more effective. I think the examples will multiply the effect and reinforce better if it is longer."

Some participants suggested that the expansion of the capacity may have role in enhancing the effects of it. K31 said:

K31 (Undergraduate, working in a state school, having an experience of 11-20 years): "The workshop was very efficient and instructive. I think these workshops should be compulsory for all educators. In the developing-renewed world, educators should be able to learn and use different teaching approaches actively in their classes."

About the sample implications shared in the workshop, 8 participants suggested that this theme is in relation with the effects of the STEM workshops. Views of K39 can be regarded as an evidence for this theme.

K39 (Graduate (MSc), working in a state school, having an experience over 21 years): "The energy of our instructor was impressive and her examples were distinguished and very useful. I'm not sure if more could have been done during this time period, but the effect of the workshop would have been even greater if the number of samples could be increased. The sample implications can be increased."

6 of the participants made recommendations about the frequency of the workshop to enhance the effect of it. All of the six participants suggested to organize workshops that they can participate free of charge more frequently. K25 said:

K25 (Undergraduate, working in a state school, having an experience over 21 years): "I suggest organizing more frequent workshops. In this way, we can achieve permanent effect with more repetitions."

2 participants suggested that the practice group size may have role in enhancing the effects of the workshop. One of them said:

K4 (Undergraduate, working in a state school, having an experience of 11-20 years): "The group size could be fewer."

\section{Discussion, Conclusion and Recommendations}

The findings of the research reveal that early STEM workshop offered for the preschool teachers had a significant and positive effect on participant preschool teachers' perceptions of early STEM practices. Although a comparison could not be made since there was no similar study that produced quantitative data conducted with preschool teachers, it can be said that parallel findings were obtained by making a comparison with the effect of applied studies with preschool children on STEM education. In this regard, it can be argued that the significant change in preschool teachers' perceptions about early STEM education from pre to post-test in this study is parallel with the findings of the study by Alade, 
Lauricella, Beaudoin-Ryan and Wartelle (2016), Aldemir and Kermani (2017), Bers, Seddighin and Sullivan (2013), Dejonckheere, Wit, Keere and Vervaet (2016), Kermani and Aldemir (2015), and Master, Cheryan and Meltzoff (2017). The results of the studies about the effects of STEM workshops on secondary school teachers' beliefs, knowledge or practice are also in line with the findings of this study (Gardner, Glassmeyer \& Worthy, 2019; Altuger-Genc, \& Issapour, 2015; Çavaş, Yar, Bula Turuplu, \& Gürcan, 2019; Yıldırım, 2020) Another comparison can be made with the qualitative studies that reveal the positive change in the scope of participant teachers' perceptions (Bozkurt Altan \& Ercan, 2016; Doğan \& Saraçoğlu, 2019; Özbilen, 2018; Yıldırım 2018; Ring, Dare, Crotty \& Roehrig, 2017). The contribution of this study is that it provides the opportunity to articulate the significance in numbers.

The qualitative analysis results indicate that preschool teachers find the STEM workshop they participated effective in six domains. The first and most focused effect is the opportunity it provides for knowledge acquisition which will be discussed together with correction /make-up in the existing knowledge. Although most of the participant teachers informed that they have already had a level of information what STEM approach is, the majority has declared that they had learned about the philosophy of the STEM approach in early childhood, why it is necessary, how it can be practiced with young children, the methodology of implementation including the planning, implementation and evaluation phases or had the chance to become aware of some misunderstandings they had. There are national and international studies pointing out the necessity of equipping teachers in STEM subjects and methods of integrating them for an effective STEM education (Eroğlu \& Bektaş, 2016; Chen, Huang \& Wu, 2020; Çavaş, Yar, Bula Turuplu \& Gürcan, 2019; Esen, Gümüşer, Ayverdi \& Avcu, 2019; Havice, Havice, Waugaman \& Walker, 2018; Kalemkuş, 2019; Siew, Amir \& Chong, 2015; Toma \& Greca, 2018; Uğraş \& Genç, 2018; Yıldırım, 2020). The participant preschool teachers' priority in manifesting the effects of STEM workshop underpin that the workshop they participated contributed to their knowledge of STEM subjects and helped to deepen their understandings of the ways to apply appropriately what they learned.

Another effect that is concluded in the study is the effect of STEM workshop on providing alternative view point in developing early childhood STEM activities and the colleague interaction during this process. Workshops allow participants to share their existing ideas and to give shape to these ideas in interaction in the implementation phase. MacDonald, Huser, Sikder \& Danaia (2019, p.362) discuss a similar outcome of the program they evaluate and conclude that it provided the participants ' $a$ space to exchange ideas and practices, and share exemplars.' Although the main purpose of the workshop is not intended on alternating view-point, it is seen that applied studies may emphasize the secondary effects such as enriching perspectives of their participants. Colleague interaction and contribution of the implementation opportunity are the other two dimensions that can be investigated in the same scope. Studies of Bell, Morrison-Love, Wooff and McLain (2018) and MacDonald, Huser, Sikder and Danaia (2019) pointed that collaborative learning networks and learning spaces are the mechanisms that lead to the achievement of the workshop's goals.

After completion of all the procedures, the participants were asked for their recommendations for an effective early childhood STEM workshop that they think will work to motivate for sustainable implementations of STEM practices in preschool classroom. Their recommendation list headed the duration of the workshop and the expansion of the capacity. The list continues with the number of samples shared, frequency of the workshop and size of the groups that performed together in their implementations. The suggestions of the participants are in accordence with the studies that determine the characteristics of effective professional development programs (Aşık, Doğança Küçük, Helvacı and Çorlu, 2017; Nadelson, Seifert, Moll and Coats, 2012; Yıldırım 2020). The findings of this study reveal that after the workshop delivered to preschool teachers, participants' STEM awareness was increased, they generated ideas for their in-class STEM implementations, compensated the knowledge they lacked or overcome the misconceptions they had about STEM implementations in early childhood and had the opportunity to interact with colleagues. However the effects are limited with one workshop which took two days. It can be recommended to conduct a number of follow up studies after the workshop is delivered. The other limitation of this study is its sample size. Although the results indicate a significant difference in preschool teachers' perceptions of early STEM practices it can not be generalized to larger 
populations. Nevertheless, it can be considered as a step taken for the academy-practitioner cooperation proposed by Aşık, Doğança Küçük, Helvacı \& Çorlu (2017).

Preschool teachers are demanding more opportunities such as hands-on experiences where they get informed about how they can implement STEM practices in their classrooms. It has been determined that the STEM workshops provide an understanding that increases the sustainability of preschool teachers' in-class implementations. Apart from the knowledge and practical contribution of the workshop, it was determined that other components inherent in the STEM approach, such as peer interaction, creating an innovative and sharing climate were also observed in the study. It can be concluded that more STEM workshops for preschool teachers can be designed with longer duration and they can be disseminated and delivered to more preschool teachers.

\section{References}

Akgündüz, D. \& Akpınar, B.Ç. (2019). Okul öncesi eğitimde STEM uygulamaları [STEM Practices in early childhood]. In D. Akgündüz (Ed.), Okul öncesinden üniversiteye kuram ve uygulamada STEM eğitimi [STEM education in theory and practice from early childhood to higher education], (pp.135-164). Ankara: An1 Publishing.

Alade, F., Lauricella, A.R., Beaudoin-Ryan, L. \& Wartella, E. (2016). Measuring with Murray: Touchscreen technology and preschoolers' STEM learning. Computers in Human Behavior, 62, 433-441. DOI: 10.1016/j.chb.2016.03.080

Aldemir, J. \& Kermani, H. (2017). Integrated STEM curriculum: improving educational outcomes for Head Start children. Early Child Development and Care, 187(11), 1694-1706. DOI: 10.1080/03004430.2016.1185102

Altuger-Genc, G. \& Issapour, M. (2015). Preparing STEM teachers for integration of NGSS: A summer workshop development. Journal of Education and Learning. 9(4), 305-313.

Aşık, G., Doğança Küçük, Z., Helvacı, B. \& Corlu, M. S. (2017). Integrated teaching project: a sustainable approach to teacher education, Turkish Journal of Education, 6(4), 200-215. DOI: 10.19128/turje.332731

Bell, D., Morrison-Love, D., Wooff, D. \& McLain, M. (2018). STEM education in the twenty-first century: learning at work - an exploration of design and technology teacher perceptions and practices. International Journal of Technology and Design in Education, 28, 721-737. https://doi.org/10.1007/s10798-017-9414-3

Bers, M. U., Seddighin, S. \& Sullivan, A. (2013). Ready for robotics: Bringing together the T and E of STEM in early childhood teacher education. Journal of Technology and Teacher Education, 21 (3), 355-377.

Bozkurt Altan, E. \& Ercan, S. (2016). STEM Education Program for Science Teachers: Perceptions and Competencies. Journal of Turkish Science Education, 13, 103-117.

Brennaman, K., Lange, A. \& Nayfeld, I. (2019). Integrating STEM into preschool education; designing a professional development model in diverse settings. Early Childhood Education Journal, 47, 1528. DOI: https://doi.org/10.1007/s10643-018-0912-z

Büyüköztürk, Ş. (2013). Sosyal bilimler için veri analizi el kitabı. Ankara: Pegem Publishing.

Bybee, R. W. (2013). The case for STEM Education: Challenges and opportunities. National Science Teachers Association, Arlington, Virginia: NSTA Press.

Campbell, C., Speldewinde, C., Howitt, C. \& MacDonald, A. (2018). STEM practice in the early years. Creative Education, 9(1), 11-25. DOI:10.4236/ce.2018.91002

Chen, Y.L, Huang, L.F. \& Wu, P.C. (2020). Preservice preschool teachers' self-efficacy in and need for STEM education professional development: STEM pedagogical belief as a mediator. Early Childhood Education Journal. Published online: https://doi.org/10.1007/s10643-020-01055-3

Copley, J. \& Padrón, Y. (1999). Preparing teachers of young learners: Professional development of early childhood teachers in mathematics and science. In Dialogue on early childhood science, 
mathematics, and technology education. Washington, DC: Project 2061, American Association for Advancement of Science.

Çorlu, M. S., Capraro, R. M. \& Capraro, M. M. (2014). Introducing STEM education: Implications for educating our teachers for the age of innovation. Egitim ve Bilim [Education and Science], 39(171).

Creswell, J. W. \& Creswell, J. D. (2017). Research design: Qualitative, quantitative, and mixed methods approaches. USA: Sage publications.

Çavaş, P., Yar, A., Bula Turuplu, S. \& Gürcan, V. (2019). Türkiye'de STEM eğitimi üzerine yapılan araştırmaların durumu üzerine bir çalışma. YYU Journal of Education Faculty, 17(1), 823-854. DOI: $10.33711 /$ yyuefd.751853

Dejonckheere, P.J.N., Wit, N.D., Keere, K.V. \& Vervaet, S. (2016). Exploring the classroom: Teaching science in early childhood. International Electronic Journal of Elementary Education, 8(4), 537558.

Doğan, E. \& Saraçoğlu, S. (2019).Views of Science Teachers on STEM-based Science Education. HAYEF: Journal of Education, 16(2); 182-220. DOI: 10.5152/hayef.2019.19016

Eroğlu, S. \& Bektaş, O. (2016). STEM eğitimi almış fen bilimleri öğretmenlerinin stem temelli ders etkinlikleri hakkındaki görüşleri. Eğitimde Nitel Araştırmalar Dergisi - Journal of Qualitative Research in Education, 4(3), 43-67. [Online] www.enadonline.com DOI: 10.14689/issn.21482624.1.4c3s $3 \mathrm{~m}$

Esen, S., Gümüşer, B., Ayverdi, L. \& Avcu, Y. E. (2019). Öğretmen, idareci, veli ve özel yetenekli öğrenci gözünden FeTeMM. Bilim, Teknoloji, Mühendislik, Matematik ve Sanat (J-STEAM) Ĕgitim Dergisi [Journal of STEAM Education], 2(2), 1-27.

Gardner K., Glassmeyer, D.M. \& Worthy, R. (2019). Impacts of STEM Professional Development on Teachers' Knowledge, Self-Efficacy, and Practice. Frontiers in Education. 4 (26), 1-10. DOI: 10.3389/feduc.2019.00026

Greenfield, D., Jirout, J., Dominguez, X., Greenberg, A., Maier, M. \& Fuccillo, J. (2009). Science in the preschool classroom: A programmatic research agenda to improve science readiness. Early Education \& Development, 20, 238-264.

Günşen, G., Uyanık, G. \& Akman, B. (2019). Okul Öncesi Öğretmenlerinin STEM Semantik Algılarının ve STEM Yaklaşımına Yönelik Düşüncelerinin Belirlenmesi. Kastamonu Education Journal, 27(4), 2173-2186. doi:10.24106/kefdergi.3387

Havice, Havice, Waugaman \& Walker, (2018). Evaluating the Effectiveness of Integrative STEM Education: Teacher and Administrator Professional Development. Journal of Technology Education, 29(2), 73-90.

Kalemkuş, J. (2019). STEM Tendency in Experimental Researches. Journal of Ziya Gökalp Faculty of Education, 36, 78-90.

Kermani, H. \& Aldemir, J. (2015). Preparing children for success: integrating science, math, and technology in early childhood classroom, Early Child Development and Care, 185(9), 1504-1527. DOI: $10.1080 / 03004430.2015 .1007371$

MacDonald, A. \& Rafferty, J. (2016). Investigating mathematics, science and technology in early childhood. Australia: Oxford University Press.

MacDonald, A., Huser, C., Sikder, S. \& Danaia, L. (2019). Effective early childhood STEM education: Findings from the Little Scientists evaluation. Early Childhood Education Journal, 48, 353-363. https://doi.org/10.1007/s10643-019-01004-9

Master, A., Cheryan, S. \& Meltzoff, A.N. (2017). Social group membership increases STEM engagement among preschoolers, Developmental Psychology, 53(2), 201-209. DOI: $10.1037 / \operatorname{dev} 0000195$

Ministry of National Education [MoNE]. (2018). STEM Approaches in a global context, Ankara: MEB Publishing.

Moomaw, S. (2013). Teaching STEM in the early years. USA: Redleaf Press. 
Nadelson, L.S., Seifert, A., Moll, A.J. \& Coats, B. (2012). i-STEM Summer Institute: An integrated approach to teacher professional. Journal of STEM Education, 13(2), 69-83.

Ndijuye \& Tandika (2020). STEM starts early: Views and beliefs of early childhood education stakeholders in Tanzania. Journal of Childhood, Education \& Society 1 (1), 29-42. DOI: 10.37291/2717638X.20201128

Ong, E.T., Ayob, A., İbrahim, N., Adnan, M., Shariff, J. \& Mohd Ishk, N. (2016). Integrating stem into early childhood education: Is it feasible? The Eurasia Proceedings of Educational \& Social Sciences (EPESS), 4, 336-341.

Özbilen, A.G. (2018). Teacher opinions and awareness about stem education. Scientific Educational Studies, 2(1), 1-21.

Polat, Ö. \& Bardak, M. (2019). STEM Approach in Early Childhood in Turkey. International Journal of Social Science Research, 8(2), 18-41.

Ring, E.A., Dare, E.A., Crotty, E.A. \& Roehrig, G. H. (2017). The Evolution of Teacher Conceptions of STEM Education Throughout an Intensive Professional Development Experience. Journal of Science Teacher Education, 28(5), 444-467, DOI: 10.1080/1046560X.2017.1356671

Siew, N. M., Amir, N. \& Chong, C. L. (2015). The perceptions of pre-service and in-service teachers regarding a project-based STEM approach to teaching science. SpringerPlus, 4(8), 1-20

Sutton, J. \& Austin, Z. (2015). Qualitative research: Data collection, analysis, and management, The Canadian Journal of Hospital Pharmacy, 68(3), 226-231.

Toma, R. B. \& Greca, I. M. (2018). The effect of integrative STEM instruction on elementary students' attitudes toward science. Eurasia Journal of Mathematics, Science and Technology Education, 14(4), 1383-1395.

Uğraş, M. \& Genç, Z. (2018). Investigating Preschool Teacher Candidates' STEM Teaching Intention and the views about STEM Education. Bartin University Journal of Faculty of Education, 7(2), 724-744. DOI: $10.14686 /$ buefad.408150

Yıldırım, B. (2018). Research on teacher opinions on STEM practices. Journal of Education, Theory and Practical Research, 4(1), 42-53.

Yıldırım, B. (2020). Preschool STEM Activities: Preschool Teachers' Preparation and Views. Early Childhood Education Journal (Published Online) DOI: 10.1007/s10643-020-01056-2

Wang, H., Moore, T. J., Roehrig, G. H. \& Park, M. S. (2011). STEM Integration: Teacher Perceptions and Practice. Journal of Pre-College Engineering Education Research (J-PEER), I(2), https://doi.org/10.5703/1288284314636 